\title{
ANALISIS FAKTOR-FAKTOR INTERNAL DAN EKSTERNAL TERHADAP PERSAINGAN BISNIS (STUDI PADA PERUSAHAAN FOOD AND BEVERAGE YANG TERDAFTAR DI BURSA EFEK INDONESIA 2002 - 2007)
}

\author{
Ardi Hamzah* \\ Universitas Trunojoyo
}

\begin{abstract}
This research objectives were to analysis the internal dan external factors on business competition, both simultanly and partially. This research done with quantitative approach. The population in this research were food and beverage firms listed in Indonesia Stock Exchanges. This research samples were manufacture firms listed in Indonesia Stock Exchanges period 2002 - 2007. Technique of taking the samples done with purposive sampling, namely firm manufacture have not negative earnings and equity for $2002-2007$. Analysis technique done with statistic descriptive and examination regression, both simultant and partial regression. The result of this research without and with lag showed simultantly internal and external variables have significant effect on business competition. For partial examination without lag showed human resources and marketing, production and finance (equities) had significant effect on business competition, while finance (liabilities), economic development, and outstanding money amount had not significant effect on business competition. In this matter indicated that human resources, marketing, production and finance specially at equities necessarily concerned related with business competition. For partial examination with lag-1 show human resources, marketing, and finance (equities) had significant effect on business competition, while production, finance (liabilities), economic development and outstanding money amount had not significant effect on business competition. In this matter indicating that human resources, marketing, and finance necessary concerned at future business competition.
\end{abstract}

Keyword: Internal and External Factors, Business Competition

\section{Pendahuluan}

Perubahan lingkungan bisnis mengalami perubahan secara radikal dengan kehadiran globalisasi. Dengan adanya globalisasi, maka sekat-sekat ekonomi antara negara satu dengan negara lain sudah tiada lagi. Perubahan ini membawa konsekuensi persaingan bisnis lebih komplek, baik yang terjadi pada level lokal, nasional dan global. Perubahan tersebut dikarenakan faktor internal berupa Sumber Daya Manusia (SDM), pemasaran, produksi dan keuangan dan faktor eksternal berupa keadaan politik, kondisi ekonomi, sosial, budaya dan ekologi serta perkembangan teknologi. SDM yang tangguh dan kompeten akan meningkatkan keunggulan persaingan bisnis, sedangkan SDM yang tidak mau berkembang dan maju akan memperpuruk kinerja perusahaan. Pemasaran yang proaktif dan progresif dengan berbagai konsep dan strategi merupakan suatu tuntutan mutlak untuk meningkatkan keunggulan persaingan bisnis. Inovasi dan kreatifitas dalam pemasaran merupakan suatu kebutuhan perusahaan yang selalu diperbaharui dan ditingkatkan untuk menghadapi persaingan bisnis perusahaan lain dalam suatu industri. Begitu pula, produksi harus ditingkatkan kualitas dan harga untuk bersaing dengan produk lain. Produk yang tidak berkualitas serta mahal harganya akan memperparah kinerja perusahaan sehingga akan terpuruk dalam persaingan bisnis. SDM, pemasaran dan produksi tanpa keuangan tidak akan berjalan. Hal ini dikarenakan sumber dana berupa keuangan merupakan "darah" bagi perusahaan. Tanpa adanya dukungan keuangan, maka SDM, pemasaran dan produksi tidak akan dapat berjalan sebagaimana mestinya. Keuangan adalah sumber dana bagi perusahaan. Dalam hal ini, sumber dana dapat dibedakan menjadi sumber 
dana internal, yaitu sumber dana yang berasal dari dalam perusahaan serta sumber dana eksternal yang berasal dari luar perusahaan.

Keunggulan persaingan bisnis tidak semata-mata ditentukan hanya dari faktor-faktor internal berupa SDM, pemasaran, produksi dan keuangan, tetapi juga ditentukan dari faktor-faktor eksternal, seperti kondisi politik, keadaan ekonomi, sosial dan budaya, perkembangan teknologi dan keadaan ekologi. Kondisi politik yang tidak stabil akan berpengaruh terhadap pencapaian keunggulan persaingan bisnis. Selain itu, kondisi politik yang tidak stabil akan memperpuruk kinerja perusahaan pada suatu industri. Keadaan ekonomi yang stabil akan mendukung peningkatan keunggulan persaingan bisnis perusahaan pada suatu industri. Kondisi sosial dan budaya yang kohesif akan mendorong dan mendukung peningkatan keunggulan bersaing. Perkembangan teknologi akan berpengaruh besar terhadap peningkatan keunggulan persaingan bisnis. Perusahaan yang menggunakan teknologi yang lebih maju akan lebih unggul dalam persaingan bisnis. Adanya ekologi yang tertata dan berkelanjutan merupakan nilai tambah bagi perusahaan dalam mencapai keunggulan persaingan bisnis. Perusahaan yang memproduksi produk yang merusak ekologi akan menurunkan keunggulan persaingan bisnis. Dengan adanya faktor-faktor internal dan eksternal tersebut, kinerja perusahaan baik dalam bentuk nilai penjualan maupun penguasaan pangsa pasar akan mengalami peningkatan. Adanya peningkatan tersebut akan menambah keunggulan dalam persaingan bisnis.

Tujuan penelitian ini untuk menganalisis dan menguji pengaruh faktor internal berupa SDM dan pemasaran, produksi dan keuangan (hutang dan ekuitas) serta kondisi perekonomian berupa Produk Domestik Bruto (PDB) dan Jumlah Uang Beredar, baik tanpa lag maupun dengan lag terhadap persaingan bisnis. Manfaat penelitian ini untuk menekankan strategi dalam penentuan faktor-faktor intern berupa SDM dan pemasaran, produksi dan keuangan serta kondisi perekonomian. Dengan adanya strategi tersebut diharapkan pencapaian keunggulan persaingan bisnis perusahaan pada suatu industri.

\section{Landasan Teori dan Pengembangan Hipotesis}

\section{Persaingan Bisnis}

Persaingan sangat penting bagi keberhasilan atau kegagalan perusahaan. Persaingan menentukan kegiatan yang perlu bagi perusahaan untuk berprestasi, seperti inovasi, budaya yang kohesif atau implementasi yang baik. Tanpa adanya persaingan tidak akan ada perbaikan, pengembangan dan peningkatan inovasi dan dinamisasi suatu perusahaan. Dengan semakin banyak dan kuatnya persaingan antar perusahaan, mau tidak mau dibutuhan strategi persaingan. Strategi bersaing merupakan upaya mencari posisi bersaing secara wajar yang menguntungkan dalam suatu industri, arena fundamental dimana persaingan berlangsung. Strategi bersaing bertujuan membina posisi yang menguntungkan dan kuat dalam kekuatan serta menutup kelemahan yang menentukan persaingan bisnis. Dengan strategi bersaing yang dapat diandalkan, maka akan tercipta keunggulan dalam persaingan. Keunggulan bersaing pada dasarnya tumbuh dari nilai atau manfaat yang dapat diciptakan perusahaan bagi para pembelinya yang lebih dari biaya yang harus dikeluarkan perusahaan untuk menciptakannya. Nilai atau manfaat inilah yang sedia dibayar oleh pembeli dan nilai yang unggul berasal dari penawaran harga yang lebih rendah ketimbang harga pesaing untuk manfaat setara atau penawaran manfaat unik yang melebihi harga yang ditawarkan. Jadi ada dua jenis dasar keunggulan bersaing, yaitu keunggulan biaya dan diferensiasi. Perpaduan antara keunggulan biaya dan diferensiasi akan meningkatkan keunggulan bersaing dan kinerja perusahaan.

Terdapat hubungan positif yang sangat erat antara kinerja suatu bisnis dan keunggulan bersaing. Kinerja suatu bisnis ditentukan oleh faktor-faktor internal perusahaan berupa Sumber Daya Manusia (SDM), pemasaran, keuangan dan produksi serta faktor-faktor eksternal perusahaan berupa lingkungan politik, ekonomi, sosial, budaya, ekologi, dan 
teknologi. Sedangkan keunggulan bersaing dapat dilihat dari seberapa besar pangsa pasar yang dikuasai dan nilai penjualan yang diraih. Semakin baik kinerja suatu perusahaan, semakin kuat keunggulan bersaing yang dimilikinya. Sebaliknya, semakin buruk kinerja suatu perusahaan, keunggulan bersaing semakin kurang. Dalam meningkatkan kinerja perusahaan diperlukan elemen-elemen keunggulan bersaing berupa: (a) Potensi keunggulan bersaing berupa keahlian yang dimiliki, sumber daya yang dimiliki dan sistem pengendalian; (b) Posisi keunggulan bersaing berupa nilai pelanggan dan biaya relatif rendah; dan (c) Kinerja yang dihasilkan berupa kepuasan, loyalitas, pangsa pasar dan daya laba.

Faktor-Faktor Internal dan Eksternal Persaingan Bisnis

\section{Sumber Daya Manusia}

Nadler L dan Nadler Z dalam Atmosoeprapto (2002) mendefinisikan Sumber Daya Manusia (SDM) sebagai pengalaman belajar yang terorganisir dalam suatu periode waktu tertentu untuk meningkatkan kemungkinan memperbaiki pertumbuhan kinerja. Pertumbuhan kinerja dalam hal ini dapat berupa peningkatan penjualan yang berdampak pada laba perusahaan maupun hubungan yang harmonis antar manusia yang berpengaruh terhadap produktifitas SDM. Peningkatan penjualan dan produktifitas SDM akan meningkatkan persaingan bisnis perusahaan pada lingkungan bisnis. Dari berbagai sumber daya yang dimiliki perusahaan, SDM menempati posisi strategis di antara sumber daya lainnya. Tanpa SDM, sumber daya yang lain tidak bisa dimanfaatkan, apalagi dikelola untuk menghasilkan suatu produk. Tetapi dalam kenyataannya masih banyak perusahaan tidak menyadari pentingnya SDM bagi kelangsungan hidup perusahaan. SDM bukan dipandang sebagai aset strategis dalam meningkatkan kinerja perusahaan dan keunggulan bersaing, bahkan tidak jarang SDM masih dianggap sebagai beban oleh perusahaan. Untuk itu, dibutuhkan perubahan-perubahan mendasar khususnya terkait dengan SDM.

Perubahan-perubahan mendasar dalam lingkungan bisnis menuntut peran serta pengelolaan SDM yang lebih besar. Berubahnya lingkungan bisnis secara dramatik ditandai dengan bergejolaknya lingkungan bisnis, kondisi bisnis yang semakin kompleks dan tidak dapat diprediksi dan meningkatnya biaya-biaya operasi serta tekanan kompetitif menciptakan tantangan bagi organisasi yang ingin meraih keunggulan kompetitif. Adanya perubahan tersebut memunculkan isu-isu SDM meliputi isu bisnis yang berkaitan dengan tenaga kerja dan isu-isu tersebut mempengaruhi esensi bisnis seperti profitabilitas, daya tahan bisnis, daya saing, kemampuan adaptasi dan fleksibilitas. Isu-isu bisnis yang berkaitan dengan SDM terus berkembang dan menyebar pada seluruh organisasi yang ada saat ini. Segala upaya yang diperlukan untuk menciptakan suatu organisasi yang berhasil tergantung pada perubahan yang signifikan dalam pengelolaan SDM. Berbagai upaya yang dilakukan organisasi untuk mencapai keunggulan kompetitif adalah: (1) Perampingan organisasi (downsizing) yang meliputi pensiun, pemberian uang pesangon, suksesi manajemen dan program-program perencanaan SDM yang lebih baik untuk mengurangi terjadinya downsizing lebih lanjut. (2) Desentralisasi melibatkan upaya melatih pekerja dalam pembuatan keputusan, penilaian kinerja, perubahan-perubahan kompensasi, dan ketrampilan kepemimpinan (leadership) yang baru.

Keunggulan kompetitif menurut Pfeffer dalam Eltan dan Anatan (2008) dapat dicapai melalui pengelolaan sumber daya manusia yang dimiliki perusahaan secara efektif. Hal ini dapat diperoleh dengan menerapkan praktik-praktik berikut secara saling berkaitan karena sulit untuk menangani suatu tindakan bila hanya diterapkan secara terpisah. Praktik-praktik tersebut adalah keselamatan kerja, keselektifan dalam perekrutan, tingkat upah yang tinggi, pemberian insentif, hak kepemilikan karyawan, pembagian informasi, partisipasi dan pemberdayaan, pengelolaan tim secara mandiri, pelatihan dan pengembangan ketrampilan, cross utilization and cross training, symbolic egalitarian, wage compression, promosi dalam perusahaaan. 


\section{Pemasaran}

Definisi Pemasaran menurut Kotler (2000) adalah suatu proses sosial dan manajerial dimana individu dan kelompok mendapatkan kebutuhan dan keinginan mereka dengan menciptakan, menawarkan dan bertukar sesuatu yang bernilai satu sama lain. Definisi ini berdasarkan pada konsep inti, yaitu kebutuhan, keinginan dan permintaan produk; produk, nilai, biaya dan kepuasan; pertukaran, transaksi dan hubungan; pasar dan pemasaran serta pemasar. Cara berpikir pemasaran mulai dengan kebutuhan dan keinginan manusia. Ada perbedaan antara kebutuhan dan keinginan. Kebutuhan manusia adalah keadaan merasa tidak memiliki kepuasan dasar. Keinginan adalah hasrat akan pemuas tertentu dari kebutuhan tersebut. Adanya kebutuhan dan keinginan tersebut, dibutuhkan konsep pemasaran untuk menciptakan, menawarkan dan bertukar sesuatu yang bernilai satu sama lain.

Ada lima konsep pemasaran yang mendasari cara organisasi melakukan kegiatan pemasarannya, yaitu (Kotler 2000): 1. Konsep Berwawasan Produksi. Konsep berwawasan produksi berpendapat bahwa konsumen akan memilih produk yang mudah didapat dan murah harganya; 2. Konsep Berwawasan Produk. Konsep berwawasan produk berpendapat bahwa konsumen akan memilih produk yang menawarkan mutu, kinerja terbaik atau hal-hal inovatif lainnya; 3. Konsep Berwawasan Menjual. Konsep berwawasan menjual berpendapat bahwa kalau konsumen dibiarkan saja, konsumen tidak akan membeli produk organisasi dalam jumlah cukup. Organisasi harus melakukan usaha penjualan dan dan promosi yang agresif; 4. Konsep Berwawasan Pemasaran. Konsep berwawasan pemasaran berpendapat bahwa kunci untuk mencapai tujuan organisasi terdiri dari penentuan kebutuhan keinginan pasar sasaran serta memberikan kepuasan yang diinginkan secara lebih efektif dan efisien daripada saingannya. Konsep berwawasan pemasaran bersandar pada empat pilar utama, yaitu pasar sasaran, kebutuhan pelanggan, pemasaran yang terkoordinir serta keuntungan; 5. Konsep Berwawasan Pemasaran Bermasyarakat. Konsep berwawasan pemasaran menghindari konflik yang mungkin terjadi antara keinginan konsumen, kepentingan konsumen dan kesejahteraan sosial jangka panjang. Adanya konsep pemasaran tersebut didukung dengan adanya strategi pemasaran dalam rangka menciptakan, menawarkan dan bertukar sesuatu yang bernilai satu sama lain.

Strategi pemasaran harus dijabarkan dalam program pemasaran. Hal ini dilakukan dengan menentukan pengeluaran pemasaran, bauran pemasaran dan alokasi pemasaran. Pengeluaran pemasaran diperlukan untuk mencapai sasaran pemasarannya. Perusahaan biasanya menetapkan anggaran pemasarannya pada persentase yang umum dari sasaran penjualannya. Bauran pemasaran adalah kelompok kiat pemasaran yang digunakan perusahaan untuk mencapai sasaran pemasarannya dalam pasar sasaran. Kiat pemasaran menurut McCarthy dalam Kotler (1994) dibagi dalam empat faktor yang disebut empat $P$, yaitu: product (produk), price (harga), place (tempat) dan promotion (promosi). Alokasi pemasaran berupa penentuan dana pemasaran pada masing-masing produk, saluran, media promosi dan daerah penjualan.

Dengan adanya konsep dan strategi pemasaran yang dapat diandalkan akan meningkatkan penjualan produk perusahaan. Penjualan tersebut akan meningkatkan pangsa pasar perusahaan. Dengan adanya peningkatan tersebut menunjukkan bahwa keunggulan persaingan berpijak pada konsep dan strategi pemasaran yang andal. Hal ini menunjukkan bahwa pemasaran mempunyai hubungan yang positif dengan persaingan bisnis. Semakin baik pemasaran yang digunakan oleh perusahaan, semakin unggul persaingan perusahaan tersebut diantara industri. Sebaliknya, semakin jelek pemasaran yang digunakan oleh perusahaan, semakin terpuruk persaingan perusahaan tersebut diantara industri. 


\section{Kevangan}

Sumber dana yang dibutuhkan dapat diperoleh dari berbagai sumber, baik sumber dana intern yang berasal dari dalam perusahaan itu sendiri, seperti penambahan modal atau ekuitas perusahaan maupun sumber dana ekstern yang berasal dari luar perusahaan itu berupa pinjaman dari lembaga keuangan perbankan maupun lembaga keuangan non perbankan. Sumber dana yang akan digunakan perlu diatur sebaik-baiknya karena masingmasing sumber dana itu memiliki konsekuensi beban keuangan sendiri-sendiri yang berbeda bagi masing-masing bentuk sumber dana itu. Sumber dana yang berasal dari kredit memerlukan beban finansial tertentu yang berupa beban yang besarnya tetap pada tiap bulan atau tahun, yaitu berupa beban bunga atas kredit. Penambahan sumber dana dibutuhkan pada saat prospek penjualan perusahaan mengalami kenaikan atau untuk meningkatkan pangsa pasar melalui perluasan promosi dan peningkatan produksi. Dengan adanya peningkatan pangsa pasar perusahaan menunjukkan adanya keunggulan persaingan bisnis perusahaan. Hubungan antara keuangan dan persaingan bisnis diduga terdapat hubungan positif. Semakin besar sumber dana keuangan yang digunakan oleh perusahaan, semakin bagus persaingan bisnis perusahaan. Sebaliknya, semakin kecil sumber dana keuangan yang digunakan oleh perusahaan, semakin jelek persaingan bisnis perusahaan.

\section{Produksi}

Proses produksi akan menghasilkan produk. Produk yang dihasilkan dapat berupa barang, yaitu benda yang berujud, akan tetapi dapat pula berupa benda tak berujud yang sering disebut jasa. Baik barang maupun jasa yang dihasilkan oleh suatu perusahaan harus direncanakan dengan baik agar produk yang diciptakan itu nanti dapat bermutu tinggi, ongkos produksinya murah dan cocok dengan selera konsumen pemakainya. Jumlah produk yang dihasilkan harus direncanakan dengan baik agar tidak terlalu banyak maupun terlalu sedikit. Bila produksi terlalu banyak tentu saja akan mengakibatkan bertumpuknya hasil produksi di gudang. Hal ini akan mengakibatkan barang tersebut dapat mengalami kerusakan dalam penyimpanannya. Disamping itu, penumpukan tersebut berarti banyak modal yang tertanam dalam barang jadi itu berhenti dan menjadi kurang efektif. Produksi yang besar menunjukkan tingkat penjualan mengalami peningkatan. Peningkatan penjualan akan berdampak pada pangsa pasar produk tersebut. Hal ini menunjukkan peningkatan produksi akan berpengaruh pada persaingan bisnis perusahaan. Hubungan antara produksi dengan persaingan bisnis diduga memiliki hubungan positif. Semakin besar produksi yang dilakukan oleh perusahaan, semakin baik persaingan bisnis perusahaan. Sebaliknya, semakin sedikit produksi yang dijalankan oleh perusahaan, semakin jelek persaingan bisnis perusahaan.

\section{Produk Domestik Bruto}

Produk Domestik Bruto (PDB) adalah nilai vang berdasar harga pasar dari semua barangbarang dan jasa-jasa yang diproduksi oleh suatu perekonomian selama suatu periode waktu tertentu biasanya satu tahun. PDB menunjukkan besarnya nilai uang dari output tahunan yang dihasilkan. Output yang dihitung nilainya dalam akuntansi PDB merupakan output akhir yaitu penjumlahan nilai output barang-barang dan jasa-jasa yang berbeda. Perusahaan yang menjual barang-barang yang diproduksinya dalam jumlah yang besar akan mempunyai kontribusi yang besar terhadap PDB. Selain itu, PDB juga memacu dan memicu perusahaan dalam persaingan untuk menghasilkan dan menjual produknya. PDB diduga berpengaruh positif terhadap persaiangan bisnis. Semakin besar PDB, semakin besar persaingan bisnis perusahaan pada industri. Sebaliknya, semakin kecil PDB, semakin kecil pula persaingan bisnis perusahaan pada industri. 
Jumlah Uang Beredar

Jumlah Uang Beredar (JUB) atau penawaran uang menurut Iswardono (1997) dalam artian sempit dapat didefinisikan sebagai jumlah seluruh vang kartal yang dipegang anggota masyarakat dan "demand deposit" yang dimiliki oleh perseorangan pada Bank-Bank Umum. Definisi yang agak luas adalah penjumlahan dari uang kartal dengan deposito berjangka (time deposit). Sedangkan definisi yang paling luas merupakan penjumlahan vang kartal, deposito berjangka dengan semua deposito pada lembaga-lembaga keuangan yang lain (nonbank). Jumlah uang beredar semakin banyak berpengaruh pada tingkat konsumsi yang dikeluarkan oleh masyarakat. Konsumsi yang besar akan mendorong perusahaan untuk memproduksi produknya untuk ditawarkan dan dijual kepada masyarakat. Dalam hal ini, produk yang diproduksi tersebut akan bersaing dalam hal harga dan mutu. Semakin murah dan bermutunya suatu produk yang dihasilkan akan meningkatkan penjualan dan pangsa pasar produk tersebut. Peningkatan tersebut menunjukkan persaingan bisnis perusahaan tersebut diantara perusahaan-perusahaan lain mengalami peningkatan. Hubungan antara JUB dengan persaingan bisnis diduga memiliki hubungan yang positif. Semakin besar JUB, semakin besar persaingan bisnis perusahaan pada industri. Sebaliknya, semakin kecil JUB, semakin kecil persaingan bisnis perusahaan pada industri.

\section{Rumusan Hipotesis}

Berdasarkan telaah literatur, maka hipotesis penelitian dapat diturunkan sebagai berikut ini: $\mathrm{H}_{1}$ : Faktor-faktor internal (Sumber Daya Manusia ${ }_{t}$ dan pemasarant, produksit dan keuangant) berpengaruh terhadap persaingan bisnis (nilai penjualant).

$\mathrm{H}_{2}$ : Faktor-faktor internal (Sumber Daya Manusiatt-1 dan pemasarant-1, produksit-1 dan kevangant-1) berpengaruh terhadap persaingan bisnis (nilai penjualant).

$\mathrm{H}_{3}$ : Faktor-faktor eksternal (Produk Domestik Brutot dan Jumlah Uang Beredart) berpengaruh terhadap persaingan bisnis (nilai penjualant).

$\mathrm{H}_{4}$ : Faktor-faktor eksternal (Produk Domestik Brutot-1 dan Jumlah Uang Beredart-1) berpengaruh terhadap persaingan bisnis (nilai penjualant).

Desain Penelitian

Secara skematis, desain penelitian untuk menggambarkan alur permasalahan dan jawaban yang diharapkan serta model pengujiannya dapat digambar sebagai berikut. 


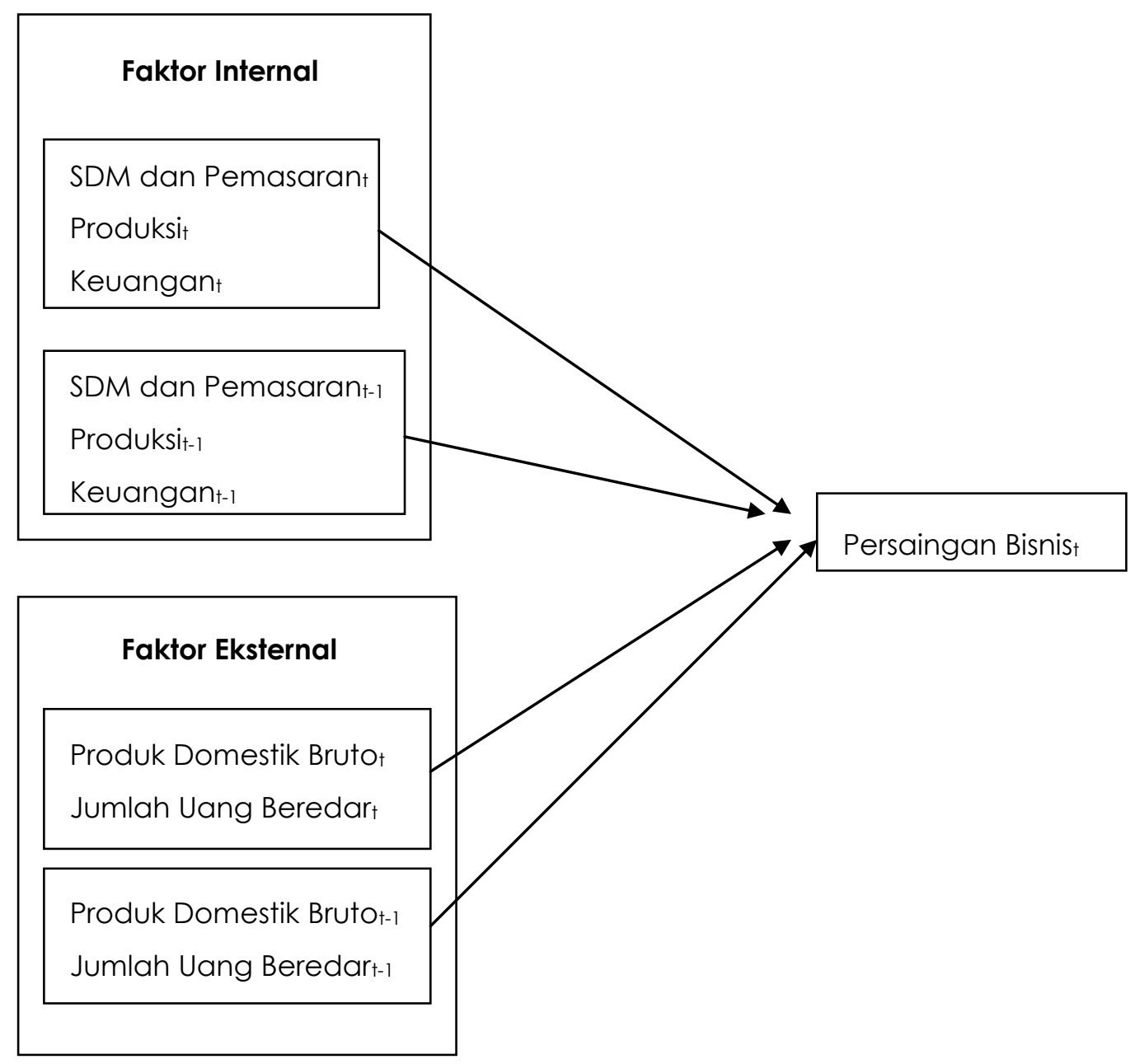

Gambar 1. Desain Penelitian

\section{Metodologi Penelitian}

Populasi dan Sampel

Populasi yang digunakan dalam penelitian ini adalah seluruh perusahaan food and beverage yang terdaftar di Bursa Efek Indonesia dari tahun 2002- 2007. Sampel dalam penelitian ini adalah perusahaan food and beverage yang terdaftar di Bursa Efek Indonesia yang tidak mempunyai laba dan ekuitas negatif selama tahun 2002 - 2007. Pemilihan sampel menggunakan metode penyampelan bersasaran (purposive sampling). Perusahaan food and beverage yang dijadikan sampel merupakan perusahaan yang memenuhi kriteria sebagai berikut: (1) Perusahaan food and beverage terdaftar di Bursa Efek Indonesia (BEI); (2) Mempublikasi laporan keuangan dengan konsisten dari tahun 2002 - 2007; (3) Periode laporan keuangan perusahaan tersebut berakhir setiap 31 Desember.

Sumber Data

Sumber data dalam penelitian ini adalah data laporan keuangan tahunan perusahaan food and beverage selama periode 2002 - 2007 yang diperoleh dari database Bursa Efek Indonesia yang tersedia di www.bei.co.id dan Indonesian Capital Market Directory (ICMD) serta data dari bi.go.id. 
Operasional Variabel dan Pengukuran Variabel

Variabel dependen dalam penelitian ini adalah persaingan bisnis, sedangkan variabel independen adalah Sumber Daya Manusia (SDM) dan pemasaran, produksi, keuangan, pertumbuhan ekonomi dan Jumlah Uang Beredar. Pengukuran persaingan bisnis diukur dengan nilai penjualan, SDM dan pemasaran diukur dengan biaya operasional, produksi diukur dengan nilai persediaan, keuangan diukur dengan nilai hutang dan ekuitas, pertumbuhan ekonomi diukur dengan Pendapatan Domestik Bruto dan Jumlah Uang Beredar diukur dengan jumlah uang kartal yang beredar.

\section{Metode Analisis}

Untuk menganalisis model tersebut digunakan analisis deskriptif dan analisis regresi. Analisis deskriptif digunakan untuk mengetahui deskripsi variabel penelitian berupa nilai minimum, maksimum, rata-rata dan deviasi standar. Analisis regresi digunakan untuk mengetahui pengaruh variabel independen terhadap variabel dependen, baik secara bersama-sama maupun parsial. Untuk mengetahui seberapa besar pengaruh variabel independen secara bersama-sama terhadap variabel dependen digunakan F-test. Untuk mengetahui seberapa besar pengaruh variabel independen secara parsial terhadap variabel dependen digunakan t-test. Model regresi berganda yang digunakan dalam penelitian ini dapat diterapkan apabila asumsi-asumsi berikut ini dapat terpenuhi. Asumsi-asumsi tersebut meliputi data terdistribusi secara normal, tidak terjadi autokorelasi, tidak terjadi multikolinearitas, dan tidak terjadi kesamaan antara varians dari residual satu pengamatan dengan pengamatan lainnya. Untuk memenuhi asumsi-asumsi tersebut, maka dilakukan uji asumsi klasik yang terdiri dari uji: (1) Uji Normalitas. Asumsi normalitas pada kesalahan penganggu akan diuji dengan menggunakan uji non parametrik, yaitu uji KolmogorovSmirnov. Pengujian data dengan uji Kolmogorov-Smirnov dapat dikatakan normal bila nilai signifikan lebih besar dari 0,05. (2) Uji Autokorelasi. Autokorelasi menunjukkan adanya kondisi yang berurutan di antara gangguan atau disturbance ei yang masuk kedalam fungsi regresi. Uji ini dilihat dari nilai Durbin-Watson berada diantara nilai du dan 4 - du yang berarti tidak terdapat korelasi. (3) Uji Mutikolinearitas. Multikolinearitas yaitu indikasi adanya hubungan linier diantara variabel independen. Multikolinearitas menunjukkan adanya hubungan antar variabel-variabel bebas. Multikolinearitas ditandai dengan nilai $\mathrm{R}^{2}$ yang tinggi namun t statistik yang rendah. Uji ini dilihat dari nilai Variance Inflation Factor (VIF) kurang dari angka 10 atau tolerance value melebihi angka 10\%. (4) Uji Heteroskedastisitas. Heteroskedastisitas menunjukkan variansi antar variabel tersebar dan tidak sama. Uji ini untuk melihat apakah ada data yang menyimpang terlalu jauh atau outlier. Ada tidaknya heteroskedastisitas dari nilai signifikansi untuk masing-masing variabel. Jika variabel independen signifikan secara statistik yaitu alfa kurang dari 10 persen $(<a=10 \%)$ terhadap nilai residual yang diberlakukan sebagai dependen variabel, maka variabel independen menunjukkan adanya heteroskedastisitas. Pengujian untuk mengetahui adanya heteroskedastisitas dilakukan dengan uji Glesjer.

\section{Hasil dan Pembahasan}

Hasil uji normalitas menunjukan nilai signifikansi kurang dari 0,05 ini menunjukkan data pada penelitian ini tidak normal. Tetapi mengacu pada rule of thumb, apabila data lebih besar dari 30, maka data tersebut dapat dianggap normal. Data penelitian ini berjumlah 234, karena lebih dari 30, maka data dapat dianggap normal. Pengujian autokorelasi menunjukkan nilai Durbin-Watson adalah 1,853. Nilai dl adalah 1,707 dan nilai du adalah 1,831. Nilai 1,853 terletak diantara du dan 4 - du atau 1,831 dan 2,169, maka data terbebas dari autokorelasi. Hasil uji multikolinearitas menunjukkan nilai Variance Inflation Factor kurang dari nilai 10 dan tolerance value melebihi angka $10 \%$. Hasil ini menunjukkan data tidak terkena multolinearitas. Hasil uji Glesjer menunjukkan nilai signifikansi alfa lebih besar dari 10 persen, ini menunjukkan data terbebas dari heteroskedastisitas. Hasil pengujian deskriptif statistik pada masing-masing variabel penelitian dapat dilihat pada tabel 1 berikut ini. 
Tabel 1.

Hasil Statistik Deskriptif

\begin{tabular}{lrrrrr}
\hline & N & Minimum & Maksimum & \multicolumn{1}{c}{ Mean } & Deviasi Standar \\
\hline Persaingan Bisnis & 861 & 7203 & 47930937 & 2152253.23 & 5781193,248 \\
SDM dan & 861 & 1551 & 5455318 & 246521,76 & 593768,846 \\
Pemasaran & & & & & \\
Produksi & 861 & 676 & 29554362 & 523808,20 & 2309466,807 \\
Keuangan (Hutang) & 861 & 43 & 46557455 & 1582424.71 & 5078521,547 \\
Keuangan (Ekuitas) & 861 & 201 & 75395776 & 1283011.18 & 5526748,312 \\
PDB & 861 & 4744500 & 5757580 & 5205570.00 & 419125,618 \\
JUB & 861 & 1919390 & 2538180 & 2231853.33 & 253000,276 \\
Valid N (listwise) & 861 & & & & \\
\hline
\end{tabular}

Sumber: Data Sekunder Diolah (2008)

Berdasarkan tabel 1 tersebut dapat dilihat untuk nilai persaingan bisnis, SDM dan pemasaran, PDB, dan JUB antara nilai minimum dan maksimum mengalami rentang yang besar, bahkan untuk nilai produksi, keuangan berupa hutang dan ekuitas nilai rentang antara minimum dan maksimum terlihat paling besar sekali. Nilai rentang antara minimum dan maksimum yang besar pada nilai penjualan menunjukkan pangsa pasar perusahaan manufaktur bervariasi. Hal ini menyebabkan nilai SDM dan pemasaran, produksi dan keuangan juga berbeda-beda pada perusahaan manufaktur.

Hasil pengujian regresi antara variabel independen dan variabel dependen, baik secara parsial maupun simultan dapat dilihat pada tabel berikut ini.

Tabel 2

Hasil Pengujian Regresi

\begin{tabular}{|c|c|c|c|c|c|c|}
\hline & \multicolumn{3}{|c|}{ Tanpa Lag ( ()} & \multicolumn{3}{|c|}{ Dengan Lag $(t-1)$} \\
\hline & Koefisien & t-test & Sig. & Koefisien & t-test & Sig. \\
\hline Konstanta & -1751315 & $-0,978$ & 0,329 & -2236591 & $-1,840$ & 0,067 \\
\hline SDM & 5,563 & 34,242 & $0,000 * *$ & 1,253 & 11,185 & $0,000^{*}$ \\
\hline \multicolumn{7}{|l|}{ Pemasaran } \\
\hline Produksi & 0,448 & 6,511 & $0,000^{*}$ & 0,130 & 2,787 & $0,006^{* *}$ \\
\hline Keuangan & $-0,019$ & $-0,740$ & 0,640 & 0,011 & 0,651 & 0,515 \\
\hline \multicolumn{7}{|l|}{ (Hutang) } \\
\hline Keuangan (Ekuitas) & 0,394 & 13,717 & $0,000^{* *}$ & $-0,041$ & $-2,091$ & $0,037^{* *}$ \\
\hline PDB & 0,881 & 0,831 & 0,407 & 1,109 & 1,541 & 0,124 \\
\hline JUB & $-1,248$ & $-0,711$ & 0,478 & $-1,455$ & $-1,220$ & 0,223 \\
\hline \multicolumn{4}{|c|}{ Adjusted R Square $=0,938$} & \multicolumn{3}{|c|}{ Adjusted R Square $=0,430$} \\
\hline \multicolumn{4}{|c|}{ F-test $=908,958 ;$ Sig. $=0,000$} & \multicolumn{3}{|c|}{ F-test $=45,497 ;$ Sig. $=0,000$} \\
\hline
\end{tabular}

Sumber: Data Diolah (2007)

Signifikan pada $a=0,01 * ; 0,05 * * ; 0,10 * * *$

Variabel Dependen $=$ Persaiangan Bisnis 
Berdasarkan Tabel 2. tersebut, pada pengujian regresi secara parsial tanpa lag ( $\dagger$ ) menunjukkan SDM dan pemasaran, produksi dan keuangan (ekuitas) berpengaruh secara positif signifikan terhadap persaingan bisnis, sedangkan keuangan (ekuitas), PDB dan JUB tidak berpengaruh secara signifikan terhadap persaingan bisnis. Hasil ini mendukung hipotesis $\mathrm{H}_{1}$ yang diajukan. Hal ini juga menunjukkan jika nilai SDM dan pemasaran, produksi dan keuangan (ekuitas) dinaikkan, maka keunggulan bersaing akan semakin tinggi. SDM dan pemasaran yang kompeten dan handal akan meningkatkan persaingan bisnis. Begitupula, produksi yang meningkat menunjukkan penjualan yang meningkat dan pangsa pasar yang semakin besar, hal ini menunjukkan keunggulan persaingan bisnis juga semakin kuat, sedangkan keuangan dalam hal ini modal atau ekuitas yang semakin besar menunjukkan kuatnya keunggulan persaingan bisnis. Pengujian secara simultan tanpa lag menunjukkan SDM dan pemasaran, produksi, keuangan (hutang dan ekuitas), PDB dan JUB berpengaruh secara signifikan terhadap persaingan bisnis. Nilai adjusted $\mathrm{R}$ square sebesar $93,8 \%$, ini menunjukkan variabel independen dapat menjelaskan variabel dependen sebesar 93,8\%, sedangkan 6,2\% dikarenakan oleh variabel-variabel lain, seperti kondisi politik, perkembangan teknologi, dan keadaan ekologi serta kondisi ekonomi lainnya.

Pada pengujian regresi secara parsial dengan lag $(\dagger-1)$ menunjukkan SDM dan pemasaran serta produksi berpengaruh secara positif signifikan terhadap persaingan bisnis, sedangkan kevangan (ekuitas) berpengaruh secara negatif signifikan terhadap persaiangan bisnis. Untuk keuangan (hutang), PDB dan JUB tidak berpengaruh secara signifikan terhadap persaingan bisnis. Hasil ini mendukung hipotesis $\mathrm{H}_{3}$ yang diajukan. Ini menunjukkan jika nilai SDM dan pemasaran serta produksi dinaikkan, maka keunggulan bersaing akan semakin tinggi, tetapi jika keuangan (ekuitas) dinaikkan, maka keunggulan bersaing akan turun. SDM dan pemasaran yang kompeten dan handal serta produksi yang meningkat akan meningkatkan persaingan bisnis, tetapi keuangan (ekuitas) yang ditingkatkan akan menurunkan keunggulan persaingan bisnis. Untuk pengujian secara simultan menunjukkan SDM dan pemasaran, produksi, keuangan (hutang dan ekuitas), PDB dan JUB berpengaruh secara signifikan terhadap persaingan bisnis. Nilai adjusted $R$ square sebesar $43 \%$, ini menunjukkan variabel independen dapat menjelaskan variabel dependen sebesar $43 \%$, sedangkan 57\% dikarenakan oleh variabel-variabel lain, seperti keadaan politik, perkembangan teknologi, kondisi ekologi serta kondisi ekonomi lainnya.

\section{Simpulan, Keterbatasan, dan Saran}

Simpulan

Berdasarkan hasil dan pembahasan, maka simpulan penelitian ini adalah sebagai berikut:

1. Nilai persaingan bisnis, SDM dan pemasaran, PDB dan JUB antara nilai minimum dan maksimum mengalami rentang yang besar, bahkan untuk nilai produksi dan keuangan (hutang dan ekuitas) nilai rentang antara minimum dan maksimum terlihat paling besar sekali.

2. Pengujian regresi secara parsial tanpa dan dengan lag (t) menunjukkan SDM dan pemasaran, produksi dan keuangan (ekuitas) berpengaruh secara positif signifikan terhadap persaingan bisnis, sedangkan keuangan (hutang), PDB dan JUB tidak berpengaruh secara signifikan terhadap persaingan bisnis.

3. Pengujian regresi secara simultan tanpa dan dengan lag ( $t$ ) menunjukkan SDM dan pemasaran, produksi, keuangan (hutang dan ekuitas), PDB dan JUB berpengaruh secara signifikan terhadap persaingan bisnis.

4. Nilai adjusted $\mathrm{R}$ square tanpa lag sebesar $93,8 \%$, ini menunjukkan variabel independen dapat menjelaskan variabel dependen sebesar $93,8 \%$, sedangkan $6,2 \%$ dikarenakan oleh variabel-variabel lain, sedangkan nilai adjusted R square dengan lag sebesar $43 \%$, ini menunjukkan variabel independen dapat menjelaskan variabel dependen sebesar $43 \%$, sedangkan $57 \%$ dikarenakan oleh variabel-variabel lain 
Keterbatasan

Penelitian mengenai analisis faktor-faktor internal dan eksternal terhadap pesaingan bisnis ini memiliki keterbatasan, antara lain sebagai berikut:

1. Variabel-variabel yang digunakan dalam penelitian ini hanya SDM dan pemasaran yang diproksi dengan biaya operasional, produksi yang diproksi dengan nilai persediaan, keuangan yang diproksi dengan hutang dan ekuitas serta kondisi ekonomi yang diproksi dengan Produk Domestik Bruto dan Jumlah Uang Beredar. Padahal masih ada proksi lain terkait dengan SDM dan pemasaran, produksi, keuangan dan kondisi perekonomian.

2. Periode penelitian hanya 6 tahun dengan sampel yang mengalami rentang nilai minimum dan maksimum yang besar pada masing-masing variabel penelitian.

Saran

Berdasarkan kesimpulan dan keterbatasan penelitian, maka saran-saran penelitian ini adalah sebagai berikut:

1. Bagi penelitian selanjutnya perlu merubah proksi SDM adalah biaya SDM, proksi pemasaran adalah biaya pemasaran, proksi produksi adalah nilai produksi yang dihasilkan, proksi kondisi ekonomi dengan harga minyak dunia, inflasi, kurs rupiah terhadap dollar dan lainnya serta perlu menambah dengan variabel lain seperti keadaan politik, sosial, dan budaya serta perkembangan teknologi dan kondisi ekologi.

2. Bagi penelitian selanjutnya perlu menyeleksi variabel-variabel yang memiliki nilai rentang minimum dan maksimum yang tidak sebegitu besar serta menambah periode penelitian.

3. Bagi penelitian selanjutnya perlu meneliti klasifikasi perusahaan-perusahaan yang masuk dalam perusahaan manufaktur.

\section{Daftar Referensi}

Anatan, Lina. 2007. Agile Manufacturing: Strategi Membangun Daya Saing Dalam Era Ekonomi Diital. The 2nd Indonesian Business Management Conference. Jakarta.

Arifin, Johan. 2002. Respon Strategik Perusahaan Perbankan Dalam Menghadapi Globalisasi. Jurnal Akuntansi \& Bisnis. UNS.

Atmosoeprapto, Kisdarto. 2002. Empower Your Human Resources. PT Elex Media Komputindo. Jakarta.

Barata, Dion Dewa. 2008. Think Local Act Global: A Diaspora Approach to Competition. The 3rd International Conference on Business and Management Research. Bali.

Barker, Alan. 2000. How to be Better at Managing People. Published by Kogan Page, Ltd.

Brahmana, Sunardi Sembiring dan Sabri, Mahmood. 2007. Resource-Based View: Market Orientation, Product Innovation, and Performance. The 2nd Indonesian Business Management Conference. Jakarta.

Ellitan, Lena. 2007. Achieving Competitive Advantage Through the Alligment Between Technology, Manufacturing Strategy and Environmental Factors: An Empirical Study of Indonesian Manufacturing Firms. Simposium Riset Ekonomi III. Surabaya.

Faulkner, David \& Bowman, Cliff. 1995. Prentice Hall International.

Hernadewita, Nizam, Mohammad and Deros, Baba. 2008. Cleaner Production Implementation Towards Competitive Advantage in Indonesian SMEs. The 3rd International Conference on Business and Management Research. Bali.

Hidayat. 2007. Etika Persaingan Dalam Komunikasi Pemasaran. The 2nd Indonesian Business Management Conference. Jakarta.

Husodo, Siswono Yudo. 2008. Pembaharuan Manajemen Bisnis Indonesia. Seminar Pembaharuan Manajemen Bisnis Indonesia. Jakarta.

Iswardono. 1997. Uang dan Bank, Badan Penerbit Fakultas Ekonomi UGM. Yogyakarta.

Kartajaya, Hermawan. 1998. Siasat Memenangkan Persaingan Global, PT Gramedia Pustaka Utama, Jakarta.

Kobs, Jims. 1979. Profitable Direct Marketing. Kobs \& Brady Advertising, Inc. 
Kochhar, Rahul. 1997. Strategic Assets, Structure Capital, and Firm Performance. Journal of Financial and Strategic Decision. Vol. 10. No. 3.

Kotler, Philip. 2000. Marketing Management. Perntice Hall, Inc.

Kotler, Philip dan Susanto, A.B. 2001. Manajemen Pemasaran di Indonesia. Penerbit Salemba Empat. Jakarta.

McDonald, Malcolm HB. 1991. Rencana Pemasaran. PT Pustaka Binaman Pressindo. Jakarta.

Meyer, Warren G, Harris, E. Edward, Kohns Donald P \& Stone, James R. 1988. Retail Marketing. McGraw-Hill, Inc.

Pearce, John A and Robinson, Richard B.1996. Strategic Management. Richard D. Irwin, Inc.

Porter, Michael E. 1985. Competitive Advantage. McGraw-Hill, Inc.

Rangkuti, Freddy. 2001. Business Plan. Penerbit PT Gramedia Pustaka Utama, Jakarta.

Rangkuti, Freddy. 2002. Creating Effective Marketing Plan, PT Gramedia Pustaka Utama. Jakarta.

Rustandi, Tandean. 2008. Pembaharuan Manajemen Bisnis Indonesia Menghadapi Persaingan Dunia Usaha yang Semakin Kompetitif. Seminar Pembaharuan Manajemen Bisnis Indonesia. Jakarta.

Skellon, Nick. 1999. Corporate Combat: The Art of Market Warfare on the Business Battlefield. Nicholas Brealey Pubishing Ltd.

Sugiharto, Totok. 2008. From Seller to Buyer Market dan Implikasinya Terhadap Change Management. Seminar Pembaharvan Manajemen Bisnis Indonesia. Jakarta.

Tambunan, Damelina B. 2008. Proactive Marketer: Cara Memenangkan Pasar yang Kompetitif. Seminar Pembaharuan Manajemen Bisnis Indonesia. Jakarta.

Tjahjono, Heru Kurnianto. 2001. Persaingan dan Perubahan Bisnis Dalam Perspektif Pembeli. Jurnal Manajemen dan Bisnis. UMY.

Tjakrawan, Paulus. 2008. Tantangan Bisnis Indonesia. Seminar Pembaharuan Manajemen Bisnis Indonesia. Jakarta.

Weston, Fred, J and Brigham, Eugene F. 1990. Essentials of Managerial Finance. Rinehart and Winston, Inc.

Widodo. 2008. Membangun Kualitas Strategi. Seminar Pembaharuan Manajemen Bisnis Indonesia. Jakarta.

Wijaya, Farid. 1997. Ekonomika Makro. Badan Penerbit Fakultas Ekonomi UGM. Yogyakarta.

Yudoko, Gatot dan Widjajani. 2007. Keunggulan Kompetitif Industri Kecil di Klaster Industri Kecil Tradisional Dengan Pendekatan Berbasis Sumber Daya. Seminar Nasional. Bandung.

\footnotetext{
*Ardi Hamzah adalah staf pengajar tetap pada Jurusan Akuntansi Fakultas Ekonomi Universitas Trunojoyo. Apabila terdapat saran, masukan, atau komentar lain dapat ditujukan melalui E-mail: hamzahardi@yahoo.com, trunojoyol@hotmail.com
} 